\title{
Diversity, Potential Utilization and Management of Cacti in Northern Kenya
}

\author{
Mary Nyawira Muchane ${ }^{1,}$, , Muchane Muchai ${ }^{2}$, Geoffrey Mungai ${ }^{1}$, William Wambugu ${ }^{1}$ \\ ${ }^{1}$ Botany Department, National Museums of Kenya, Nairobi, Kenya \\ ${ }^{2}$ Department of Clinical Studies (Wildlife Management \& Conservation Section), College of Agriculture and Veterinary Sciences, University \\ of Nairobi, Nairobi, Kenya
}

Email address:

mmurethi@yahoo.com (M. N. Muchane)

${ }^{*}$ Corresponding author

\section{To cite this article:}

Mary Nyawira Muchane, Muchane Muchai, Geoffrey Mungai, William Wambugu. Diversity, Potential Utilization and Management of Cacti in Northern Kenya. International Journal of Natural Resource Ecology and Management. Vol. 2, No. 6, 2017, pp. 104-113.

doi: $10.11648 /$ j.ijnrem.20170206.12

Received: October 6, 2017; Accepted: November 2, 2017; Published: December 25, 2017

\begin{abstract}
Cactus family (Cactaceae) is popular horticultural plant group with worldwide introduction outside their native ranges for ornamental purposes or as drought tolerant crops for arid and semi-arid lands (ASALS). Despite their importance the species are also the most damaging invasive, yet very little information exists about their status, diversity, potential utilization and problems associated with their management. Field and socio-economic surveys were carried out in ASALs of Northern Kenya to document (i) abundance and diversity of introduced Cactus species, (ii) identify reasons for their introduction, (iii) find potential uses and any invasive problems associated with introduced species. Field methods recorded species richness and abundance of cactus species while socio-economic methods recorded local knowledge on potential utilization and problems associated with management of Cactus species using semi-structured questionnaires. This study recorded only three species of cactus; Opuntia ficus-indica (both spined and spineless), Opuntia exaltata and Cereus peruvianus. The species were found mainly in settled areas and within urban centres. The species were introduced as ornamental (horticulture), dry land crop with ability to provide food (fruits and vegetable) or fodder (for humans or livestock) and as live fences due to their ability to thrive dry conditions. Cactus species in particular O. ficus-indica plays an important role in the region in providing fodder and fruits in the extremely dry seasons. Although cactus species in this region are not yet problematic weed, overgrowth if left unmanaged and thorns were cited as major problems associated with its introduction necessitating sustainable management options to avoid any invasive problem. Proper management of the spineless variety has great potential in improving rural livelihoods.
\end{abstract}

Keywords: Cactus, Utilization, Management, ASALs, Invasive, Northern Kenya

\section{Introduction}

Arid and Semi-arid lands (ASALs) cover one-third of the earth's land surface with more than $50 \%$ of the land in developing countries and $55 \%$ of the African land mass supporting quarter of the earth's population [1]. In Kenya, more than two thirds of total land surface $(80 \%)$ is classified as dry land, and host approximately $20 \%$ of the total human population, and slightly half of the total livestock population [2]. The dry areas resources are among the most threatened resources in Kenya by the ever increasing human and livestock population and drought prevalence which have resulted in a constant ecological degradation. The result of this is continued inter-community fighting for the declining resources, which in return is deteriorating the quality of life of the people and posing threats to their survival [2]. There is need to use dry areas zones more productively by identifying, developing and advocating for wise utilization of the potential crops, which tolerate dry conditions and management of any invasive species that may decline their productivity.

Cactus family (Cactaceae) is a large and diverse group of stem succulents predominantly occurring in warm and arid 
north and South America [3]. Cacti species are among the popular horticultural plant groups with worldwide introduction outside their native ranges for ornamental purposes or as drought tolerant crops in ASALS [4]. The species have wide introduction and adaptation in dry and warm climate such as Australia, the Mediterranean and East Africa [5, 6]. Their distribution encompasses various habitats, including bare, hot deserts, sandy coastal stretches, scrublands, dry deciduous forests, high alpine steppes, and even tropical rain forests [7]. Most of the cactus family members have numerous uses. Among other most important cactus species is prickly pears (Opuntia. ficus-indica L. Mill) grown for the large and sweet fruits available in local and commercial markets worldwide [8, 9]. Important growing regions include Mexico, Sicily, Algeria, Chile, Brazil, and northern Africa [9, 10]. In addition, young cladodes (stem segments) of $O$. ficus-indica are harvested as a vegetable crop available in many local and commercial markets [11]. Other uses of O. ficus-indica include binding and waterproofing agent in adobe [12], medicinal properties [13] and host plant for cochineal insects (Dactylopius coccus) used in production of valuable, vivid red and purple dyes [14-16].

Despite these economic gains, cactus species are also the most damaging introduced invasive species causing biodiversity and economic losses worldwide (4). Cactus invasion has been reported in Australia, Africa and Europe [4, 17-22]. The easiness of Cactus vegetative propagation through clonal, abundance of photosynthetic tissue, shallow root structure, and ability to perform CAM photosynthesis makes it a noxious weed that out competes many other indigenous species [6, 23-25]. Presence of big and small hairlike spines makes its management and eradication difficult. Despite various documented economic importance and challenges, very little information exists about these species in Africa, Kenya included. Due to the growing interest in cultivation of many cacti to eradicate desertification $[4,5,6$, $9,10]$, new introduction and invasion are expected even before proper management strategies are developed. There is therefore need to understand introduced Cactus diversity, management and their potential utilization especially in ASALs where they have become naturalized. This knowledge will be very vital while promoting their utilization in the wild (and or cultivation) and in facilitating development of management strategies that may eradicate future invasion.

This study was undertaken to explore (i) abundance and diversity of introduced Cactus species and (ii) identify reasons for their introduction, current uses, potential utilization and sustainable management constraints in Northern Kenya.

\section{Materials and Methods}

\subsection{Study Area}

The study was conducted Northern Kenya in Samburu (Maralal, Baragoi) and Marsabit County (South Horr, Loiyangalani) all located in the North Rift Valley Region (Figure 1). The area lies between $1^{\circ} 04^{\prime} \mathrm{N}-2^{\circ} 45^{\prime}$ and $36^{\circ} 42^{\prime}$ $36^{\circ} 55^{\prime} \mathrm{E}$ longitude (Table 1 ). The region lies between $200 \mathrm{~m}$ above sea level in lowland areas of Lake Turkana and $2050 \mathrm{~m}$ in highland areas around Maralal town. The climate of the region is arid and semi-arid with average annual rainfall of $200 \mathrm{~mm}$ in lowland of Lake Turkana and $400 \mathrm{~mm}$ highland regions. The study area has an average temperature of $24^{\circ} \mathrm{C}$. The climate of this region is influenced by altitude. Lowlands and plains experience high temperatures and relatively low rainfall while highlands have sub-tropical climatic conditions with low temperatures, low evaporation rates and high rainfall. The vegetation cover of the lowland is acacia woodland while that in highland zone comprises of wooded grassland with scattered and some cases dense Acacia dominated forests which serve as major water catchments for the entire region. The area is sparsely populated, with settled areas along main roads and major towns. Pastoralism is the major economic activities. Rain fed agriculture is only restricted along major rivers valleys where crops like millet, sorghum, cassava, bananas, cotton and vegetables are grown. Other economic activities include honey production, hunting, making and selling of ornaments from local materials, basketry and sale of medicinal herbs.

Table 1. Description of eleven (11) study sampling sites (block).

\begin{tabular}{llllll}
\hline \multirow{2}{*}{ Site } & Transect & Location & & \multicolumn{2}{c}{ Temperature } \\
\cline { 2 - 5 } & & Latitude & Longitude & Altitude & ${ }^{\circ} \mathbf{C}$ \\
\hline Maralal & 1 & $1^{\circ} 04^{\prime} \mathrm{N}$ & $36^{\circ} 32^{\prime} \mathrm{E}$ & 1945 & 24 \\
Poro & 2 & $1^{\circ} 12^{\prime} \mathrm{N}$ & $36^{\circ} 60^{\prime} \mathrm{E}$ & 2050 & 23 \\
Morijo A & 3 & $1^{\circ} 24^{\prime} \mathrm{N}$ & $36^{\circ} 40^{\prime} \mathrm{E}$ & 2044 & 23 \\
Morinjo B & 4 & $1^{\circ} 37^{\prime} \mathrm{N}$ & $36^{\circ} 44^{\prime} \mathrm{E}$ & 2025 & 25 \\
Morijo C & 5 & $1^{\circ} 47^{\prime} \mathrm{N}$ & $36^{\circ} 47^{\prime} \mathrm{E}$ & 1268 & 27 \\
Baragoi A & 6 & $1^{\circ} 57^{\prime} \mathrm{N}$ & $36^{\circ} 53^{\prime} \mathrm{E}$ & 1268 & 27 \\
Baragoi B & 7 & $2^{\circ} 12^{\prime} \mathrm{N}$ & $36^{\circ} 56^{\prime} \mathrm{E}$ & 1145 & 300 \\
South Horr A & 8 & $2^{\circ} 21^{\prime} \mathrm{N}$ & $36^{\circ} 52^{\prime} \mathrm{E}$ & 1145 & 30 \\
South Horr B & 9 & $2^{\circ} 32^{\prime} \mathrm{N}$ & $36^{\circ} 45^{\prime} \mathrm{E}$ & 450 & 30 \\
Loiyangalani A & 10 & $2^{\circ} 32^{\prime} \mathrm{N}$ & $36^{\circ} 45^{\prime} \mathrm{E}$ & 450 & 31 \\
Loiyangalani B & 11 & $2^{\circ} 45^{\prime} \mathrm{N}$ & $36^{\circ} 433^{\prime} \mathrm{E}$ & 300 & 200 \\
\hline
\end{tabular}


Table 1. Continued.

\begin{tabular}{lll}
\hline Site & $\begin{array}{l}\text { Distance from } \\
\text { Marala Town }\end{array}$ & Vegetation \\
\hline Maralal & 0 & Wooded grassland with scattered tree species (Acacia nilotica, Acacia seyal, Ricinus communis, Juniperus procera, \\
Poro & 25 & Euphorbia candelabrum, Psidian punctulata, Euclea divinorum, Carissa edulis) \\
Morijo A & 50 & Wooded grassland with fairly dense but scattered tree species (Acacia brevicpica, Cordia purpurea, Euphorbia \\
Morinjo B & 75 & heterochroma, Duosperma eremophyalla, Prosopis juliflora, Kleimia kleinoides, Balanite aegyptica, Euphorbia \\
Morijo C & 100 & uglilii) \\
Baragoi A & 125 & Dry grassland, acacia, and cactus and dwarf shrubs with no agricultural activities \\
Baragoi B & 145 & \\
South Horr A & 175 & Wooded grassland with sparsely spread Acacia trees, Balanites aegyptiaca and dry under growth grassland. \\
South Horr B & 200 & Rocky and Grassy plains with speargrass (Imperata cylindrical) and scattered tree species (Commiphora sp. Acacia \\
Loiyangalani A & 225 & tortilis, A. elatior, Balanites aegyptiaca) and doum palm (Hyphaene coriacea) along water oasis \\
Loiyangalani B & 233 &
\end{tabular}

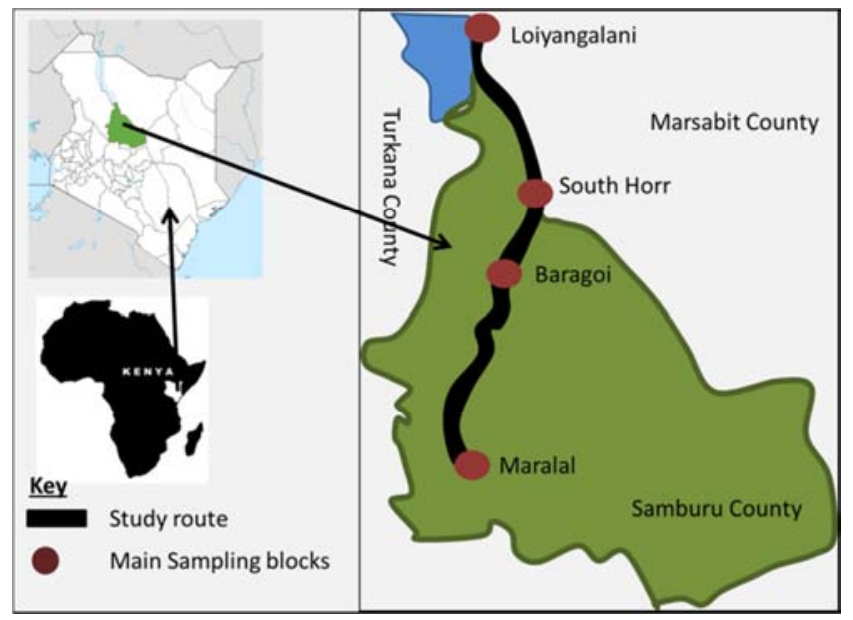

Figure 1. Map of study area showing main sampling block; Maralal, Baragoi, South Horr and Loiyangalani in Northern Kenya.

\subsection{Experimental Design, Collection and Identification of Cactus Species}

The survey was done using a standard method of vegetation assessment. Eleven study blocks were identified along Maralal-Loiyangalani road transect, with our first block situated at Maralal town $(0 \mathrm{~km})$. The study blocks were $25 \mathrm{~km}$ away and included Maralal $(0 \mathrm{~km})$, Poroo $(25 \mathrm{~km})$, Morijo A $(50 \mathrm{~km})$, Morijo B (75 km), Morinjo C (100km), Baragoi A $(125 \mathrm{~km})$, Baragoi B $(150 \mathrm{~km})$, South horr $(175 \mathrm{~km})$, South Horr B (200km), Loiyangalani South $(225 \mathrm{~km})$ and Loiyangalani North $(236 \mathrm{~km})$. In each block one (1) km transect was installed $100 \mathrm{~m}$ away from the main road. Five sampling plots of $5 \times 5 \mathrm{~m}$ were demarcated $200 \mathrm{~m}$ apart along $1 \mathrm{~km}$ transects using Permanent markers (with their GPS readings). A total of 55 sampling plots were used for this study. Cactus species within or with parts leaning into the plot were identified and the percentage of the plot covered by each species was recorded. Percentage cover was chosen as a measure of abundance because many cactus species are clonal, making it difficult to distinguish between discrete individuals [26]. Percentage cover was estimated visually in $1 \%$ intervals up to $5 \%$, then by $5 \%$ intervals up to $100 \%$. Encountered cactus species were collected and identified by consulting the East Africa Herbarium where necessary.

\subsection{Socio-Economic Survey}

Social economic survey was carried out in three regions (Maralal, Baragoi and Loiyangalani) using semi-structured questionnaires to establish reasons for cactus introduction, levels of awareness, current uses, potential of cultivating cactus species as food and fodder provision and any possible management constraints. The sites were chosen based on abundance of species recorded. In each area, 20 households were randomly selected. Semi-structured interviews guided by semi-structured questionnaire were conducted with any member of the household above 18 years old. The questionnaire was divided in three thematic sections: (A) Information on socio-cultural and economic characteristic (family size, gender affiliation and age of respondents), (B) Awareness, reasons for introduction, current uses, (C) Cultivation potential for food and fodder provision and possible management constraints. A total of 60 household respondents were interviewed in the entire region.

\subsection{Data Analysis}

The Cactus species abundance was estimated as percentage ground cover per each $5 \times 5 \mathrm{~m}$ plot $\left(25 \mathrm{~m}^{2}\right.$ area). The data was used to estimate species richness and abundance in each sampling site (block) using PAST programme [27]. One-way ANOVA were performed to assess effects of site (block) on species richness, total abundance (percentage ground cover) and individual species abundance. Differences between site means were separated by Turkey's post hoc test at $\mathrm{P}<0.05$. Percentage and count data was tested for normality, and percentage data was arcsine transformed while count data were logarithm $(\log +1)$ transformed to ensure conformity of the data with ANOVA assumptions. Mean value of all the data are presented alongside standard error (SE) of the means. Diversity measures were not calculated due to low number of species observed. Socioeconomic data was analysed using descriptive Statistics such as percentages. The data are presented graphically or in a table.

\section{Results and Discussions}

\subsection{Cactus Species in Northern Kenya}

Cactus plants were introduced in Kenya during the pre- 
colonial period. The first record of cactus in Kenya was recorded in 1933, and since then five more species (Opuntia exaltata, Opuntia ficus-indica, Opuntia cocheniffera, Opuntia streptacantha and Rhisphalis baccifera) have been documented [28]. In this study three (3) species distributed in two genera (Opuntia and Cereus) were recorded (Table 2). Two Opuntia species included Opuntia ficus-indica Mill comprising of two varieties, spineless (Figure 2) and spined (Figure 3) varieties and Opuntia exaltata A. Berge (Figure 4). Cereus genus comprised of one species, Cereus peruvianus Haw (Figure 5). The species were introduced in Kenya as ornamentals during the colonial period [28]. Record of O. ficus-indica was expected in this study, since is among the several long-domesticated cactus species and is widely used as ornamentals and in landscaping $[29,30]$. Opuntia exaltata though introduced as ornamental is currently used by local community as live hedge to exclude livestock, large and small wild mammals.

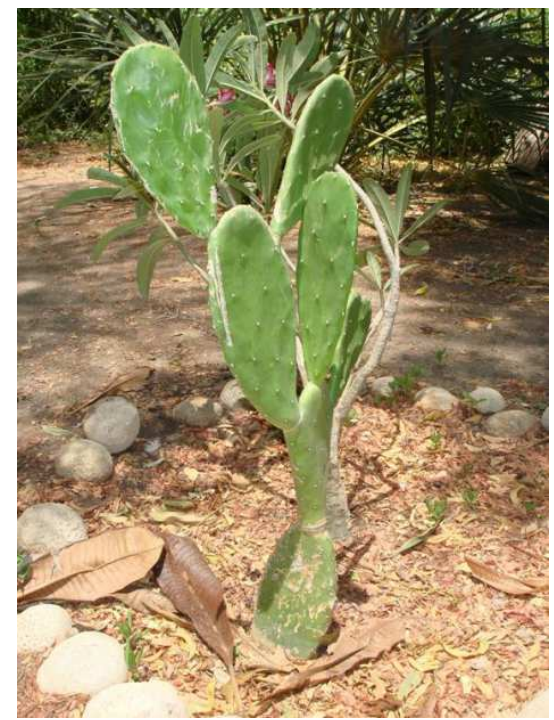

Figure 2. Spineless Opuntia ficus-indica in Loiyangalani catholic mission, Northern Kenya.

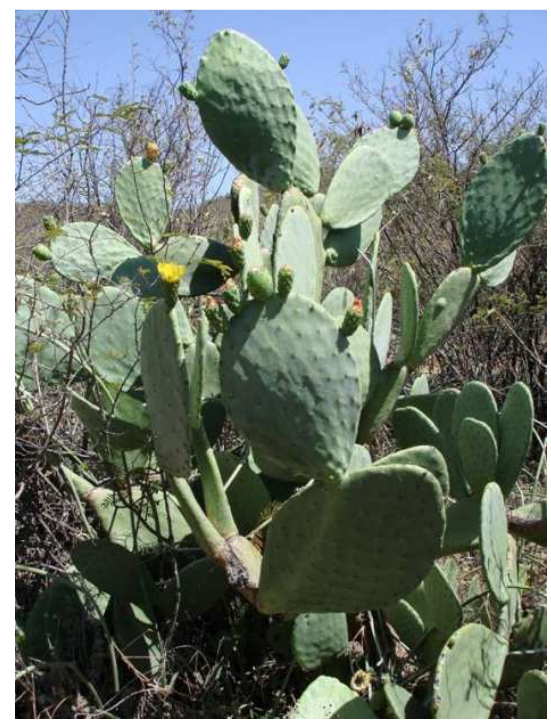

Figure 3. Spined Opuntia ficus-indica variety in Morijo $(50 \mathrm{~km}$ from Maralal), Northern Kenya.

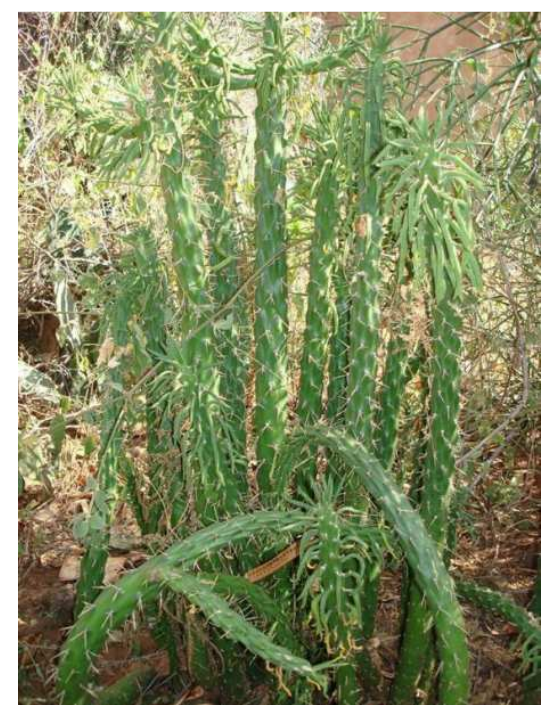

Figure 4. Opuntia exaltata in Baragoi (145km from Marala town), Northern Kenya.

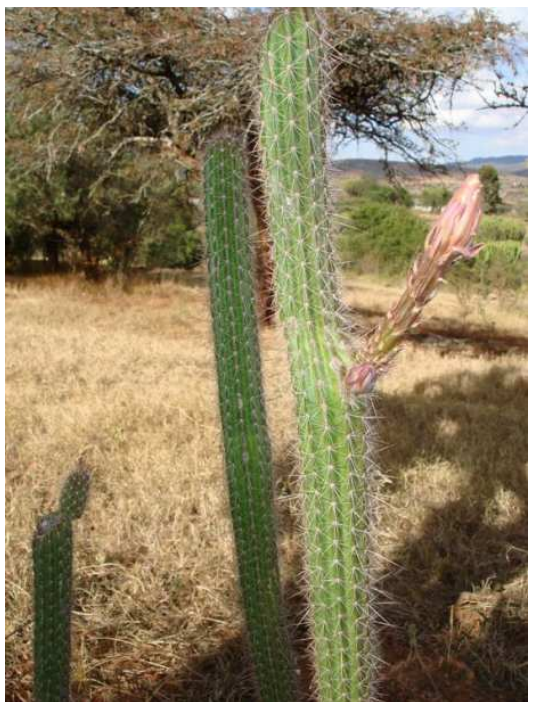

Figure 5. Cereus peruvianus in Maralal $(0 \mathrm{~km})$, Northern Kenya.

This study revealed introductions of Cereus peruvianus and $O$. ficus-indica spineless variety, which had not been documented in Kenya before, according to Flora of Tropical East Africa [28]. Cereus peruvianus (apple cactus) is a large erect, thorny columnar cactus found in South America. It is mainly planted as an ornamental and is recorded among the most promising cactus species in dry region in terms of its rapid growth and precocious early yielding [31-33]. In this area Cereus peruvianus could have been introduced as ornamentals within the urban areas. Alternatively, O. ficusindica spineless variety was a recent introduction in Loiyangalani from Marsabit region. It is also long domesticated plant, and has a wide usage as fodder [6]. Results of this study suggest need for more detailed studies in other regions in Kenya to document all cactus species. The last report of Cactaceae species in Kenya is Flora of Tropical East Africa [28]. Since then, many more cactus species could have been introduced. Here we have shown introductions of Cereus peruvianus and $O$. ficus-indica spineless cultivar not 
documented earlier. Opuntia stricta has also been shown to occur widely in Kenya with recent introduction of less than ten years [19].

\subsection{Cactus Species Richness, Abundance in Northern Kenya}

Sampling sites significantly influenced Cactus species richness $(\mathrm{F}=10.71, \mathrm{p}<0.001)$ and abundance $(\%$ ground cover, $\mathrm{F}=3.347, \mathrm{p}=0.003$ ). Maralal town recorded all the three cactus species, highest species richness and abundance followed by Baragoi which had two species namely Opuntia exaltata and Opuntia ficus-indica (Table 2, Figure 6-7). O. ficus-indica was the only cactus species found at Loiyangalani and South Horr with evidences of recent introductions (Table 2, Figure 6-7). South Horr and Loiyangalani had the least species abundance and richness only recorded in sites near the settled areas and in urban centres $(175 \mathrm{~km}$ and $236 \mathrm{~km}$, Figure $6-7)$. In all the sampling sites, the three species were recorded either in previously settled areas or near urban centres.

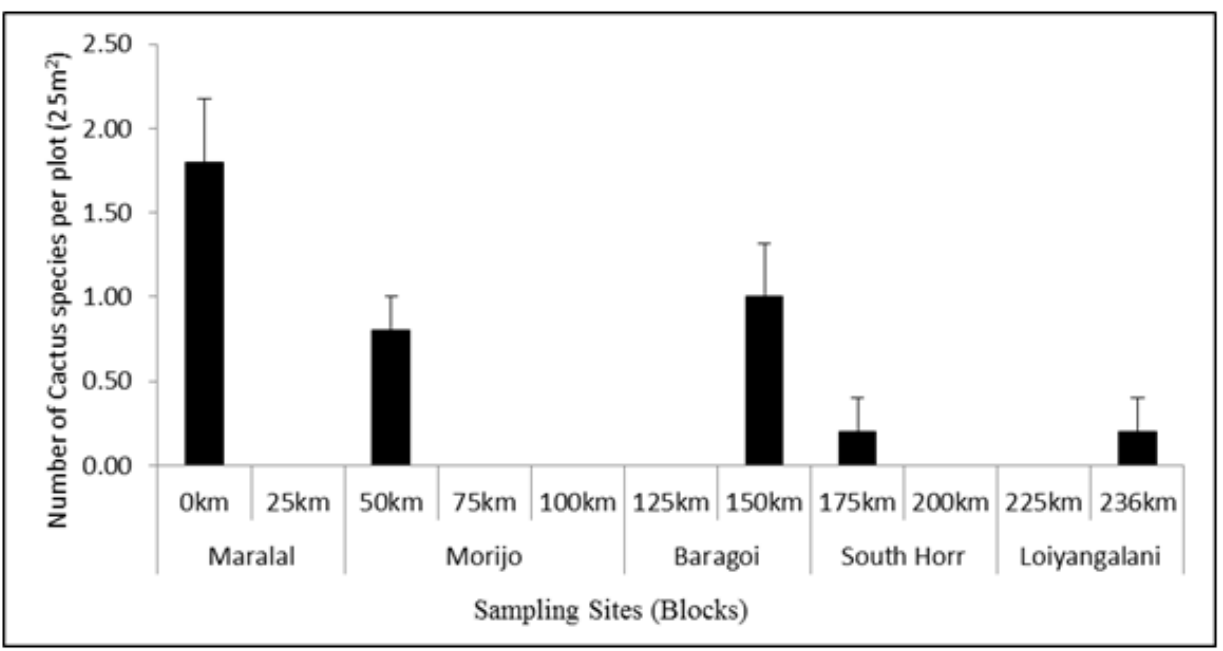

Figure 6. Cactus species richness (number of species per $25 \mathrm{~m}^{2}$ ) across the study sites in Northern Kenya. Okm-Maralal, $25 \mathrm{~km}$-Poro, $50 \mathrm{~km}$-Morijo A, $75 \mathrm{~km}$ Morijo B, 100km-Baragoi A, 125km-Baragoi B, 145km-Baragoi (C) town, $175 \mathrm{~km}$ represents South Horr A, 200 South Horr B, 225km- Loiyangalani. Error bars represents standard error (SE).

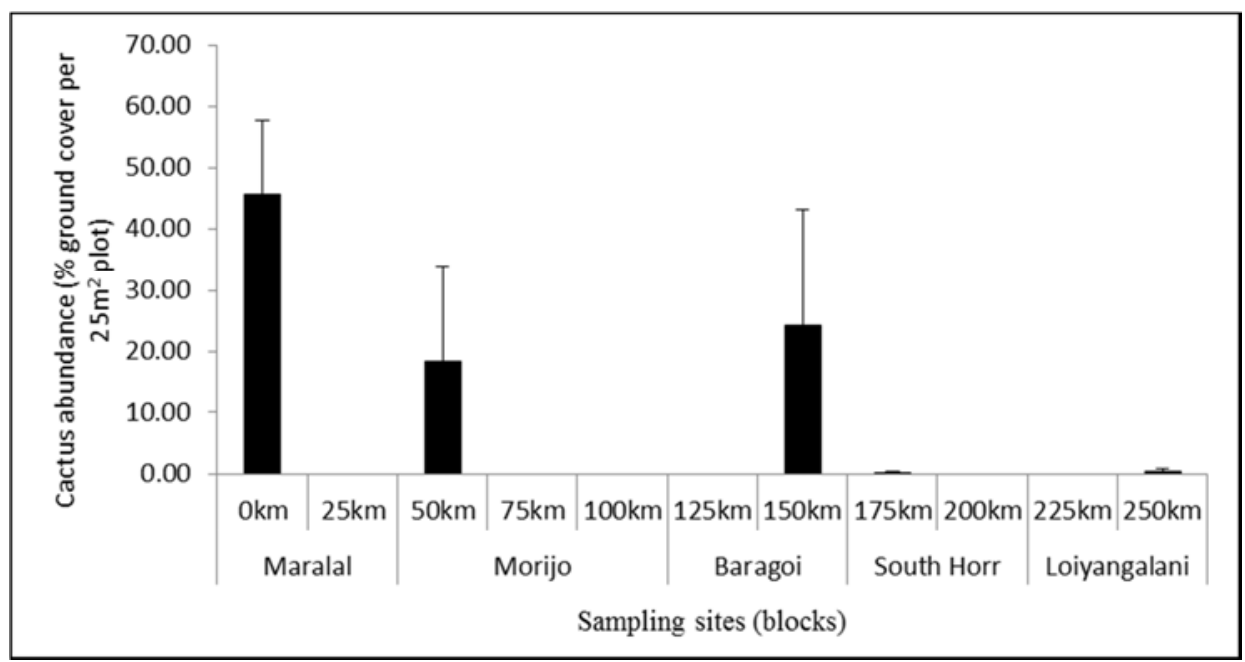

Figure 7. Cactus species abundance (\% ground cover per sampling plot, $25 \mathrm{~m}^{2}$ ) across different study sites in Northern Kenya. 0km-Maralal, $25 \mathrm{~km}-$ Poro, 50km-Morijo A, 75km-Morijo B, 100km-Baragoi A, 125km-Baragoi B, 145km-Baragoi (C) town, $175 \mathrm{~km}$ represents South Horr A, 200 South Horr B, $225 \mathrm{~km}$ Loiyangalani. Error bars represents standard error (SE).

Table 2. Cactus species recorded in Northern Kenya and their uses.

\begin{tabular}{|c|c|c|c|c|c|c|c|c|}
\hline \multirow{2}{*}{ Cactus species } & \multirow{2}{*}{ Uses } & \multicolumn{2}{|c|}{ Maralal } & \multicolumn{2}{|c|}{ Morijo } & \multicolumn{3}{|c|}{ Baragoi } \\
\hline & & $\mathbf{0 k m}$ & $25 \mathrm{~km}$ & $50 \mathrm{~km}$ & $75 \mathrm{~km}$ & $100 \mathrm{~km}$ & $125 \mathrm{~km}$ & $145 \mathrm{~km}$ \\
\hline Opuntia exaltata A Berge & ORN, LF, NDLs & + & - & - & - & - & - & + \\
\hline Opuntia ficus-indica (L) Mill & ORN, LF, NDLs, FD, FDD, MD & + & - & + & - & - & - & + \\
\hline Cereus peruvianus & ORN & + & - & - & - & - & - & - \\
\hline
\end{tabular}


Table 2. Continued.

\begin{tabular}{llllll}
\hline \multirow{2}{*}{ Cactus species } & \multirow{2}{*}{ Uses } & South Horr & & Loiyangalani \\
\cline { 2 - 5 } & & $\mathbf{1 7 5} \mathbf{k m}$ & $\mathbf{2 0 0 k m}$ & $\mathbf{2 2 5} \mathbf{k m}$ & $\mathbf{2 3 2} \mathbf{k m}$ \\
\hline Opuntia exaltata A Berge & ORN, LF, NDLs & - & - & - & - \\
Opuntia ficus-indica (L) Mill & ORN, LF, NDLs, FD, FDD, MD & + & - & - & + \\
Cereus peruvianus & ORN & - & - & - & - \\
\hline
\end{tabular}

Key; ORN-Ornamental, LF-Live fences, NDLs-Needles, FD-Food (fruits), FDD-Fodder and MD-Medicine,

The results of this study suggest that urbanization, development and accessibility are the major factors influencing presence, species richness and abundance of cactus species in this area. Maralal town is among the old towns in this area. It is also more developed compared to other urban centre in this region (Baragoi, South horr, Lioyangalani) and is easily accessible with well-developed and accessible road network. Inception of modern guest house and modern Catholic mission at South Horr and Loiyangalani respectively and development of the road network have seen the introduction of $O$. ficus-indica species in these two regions. In Loiyangalani, two varieties (both spineless and spined, Figure 2,3) of the O. ficus-indica were recorded in a newly established catholic mission site for ornamental purposes. The results of this study support finding showing cactus species colonizing areas located less than $200 \mathrm{~m}$ within the vicinities of urban settlements [35]. This indicates humans are the main means of cactus dispersal, suggesting a wide spread of the species as a result of anthropogenic dispersal via garden throw-outs [36] or by deliberated planting as ornamentals, after which cactus colonize and expands its range into the surrounding shrublands [35]. The ease of the species to propagate from segments, explains its rapid spread. When the fallen segment is exposed to diffuse sunlight for 7-15 days, it partially withers improving the rooting and proliferation of pads. We predict a wide spread of these species with expected increase in modern facilities and urban development with time. There is urgent need to educate the local communities about the potential utilization, management options and the dangers, threats and impacts of this invasive species.

Individual species abundance in this region were also significantly affected by sampling sites $(\mathrm{p}<0.05)$. Opuntia exaltata abundance was high in Maralal $(0 \mathrm{~km})$ while $O$. ficus-indica abundance was high in Morijo $(50 \mathrm{~km})$ (Figure 8). In Baragoi (145km) Opuntia exaltata and O. ficusindica abundance did not differ significantly $(\mathrm{p}>0.05)$ while abundance of $O$. ficus-indica was extremely low in South Horr and Loiyangalani. Cereus peruvianus only occurred in Maralal and its abundance was extremely low $(<1 \%$ ground cover). Although most of cactus species were initially introduced as ornamentals and for hedging purposes, these species tend to spread to other non-targeted areas due to their easiness to propagate through clodades $[20,36]$. Lack of any management further increase their spread and invasion non-targeted areas [19]. High abundance observed in Maralal, Baragoi and Morijo may be associated with species spread to non-targeted areas where management or attempts to remove or control are not applied. O. ficusindica was a recent introduction in South Horr and Loiyangalani explaining their low level of abundance. Cereus peruvianus was also a new introduction in Maralal Kenyatta House Museum. This implies need for community awareness on benefits and management of these species to control spread to non-targeted areas to minimize any future negative impacts.

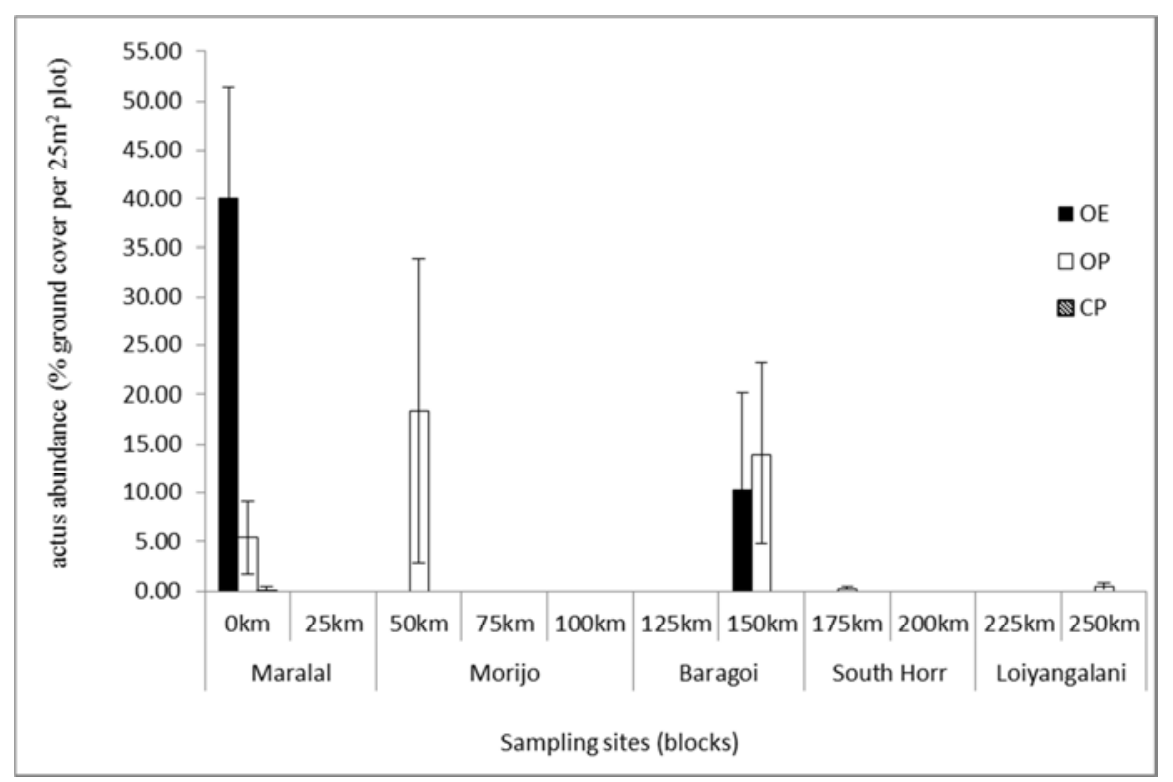

Figure 8. Distribution and abundance (\% ground cover per $\left.25 \mathrm{~m}^{2}\right)$ for three cactus species; Opuntia exaltata-OE, O. ficus-indica-OP and C. peruvianus-CP across different study sites in Northern Kenya. Okm-Maralal, $25 \mathrm{~km}$-Poro, $50 \mathrm{~km}$-Morijo A, $75 \mathrm{~km}$-Morijo B, 100km-Baragoi A, $125 \mathrm{~km}$-Baragoi B, $145 \mathrm{~km}$ Baragoi (C) town, $175 \mathrm{~km}$ represents South Horr A, 200 South Horr B, 225km-Loiyangalani. Y error bars represents standard error (SE). 


\subsection{Socio-Economic Surveys}

\subsubsection{Awareness, Reason for Introduction and Current Uses}

Local communities in this region are generally aware of Cactus species and their possible uses. More than $40 \%$ of people interviewed were aware of presences of Cactus species and had directly or indirectly used them (Table 3 ). Maralal recorded the highest level of cactus awareness (45\%), followed by Baragoi (40\%). Loiyangalani (25\%) had the least level of awareness. Cactus species in this area were introduced for three main reasons. Thirty $(30 \%)$ percent of people interviewed cited ornamental as major reason for introduction of Cactus species, followed by live fences $(28 \%)$ while drought resistant crop was least with only $5 \%$ respondents all from Loiyangalani (Table 2). In settled and urban area especially in Maralal and Baragoi, $O$. ficus-indica was introduced as ornamental (horticulture) species due to its ability to thrive dry conditions. Opuntia ficus-indica was also introduced in Marsabit County as dry land crop with ability to provide food (fruits and vegetable) or fodder (i. e. for humans or livestock). In Maralal and part of Baragoi, O. exaltata and $O$. ficus-indica were introduced for hedging around the home compounds. This is in line with earlier reports showing major driver of Cactus spread as ornamental and hedges $[20,22]$. The growing interest in cultivation of $O$. ficus-indica for fruit and fodder production introduced the spineless $O$. ficus-indica in Marsabit [6].

Table 3. Demographic characteristics of the respondents, level of their awareness, reasons for Cactus introduction and current uses of Cactus species in the region.

\begin{tabular}{|c|c|c|c|c|}
\hline & & Loiyangalani & Maralal & Baragoi \\
\hline & & $\%$ & $\%$ & $\%$ \\
\hline \multicolumn{5}{|c|}{ Section A: Awareness of Cactus and its known uses } \\
\hline \multirow[t]{3}{*}{ Age of respondents in years } & $18-20$ & 20 & 25 & 15 \\
\hline & $20-40$ & 45 & 20 & 50 \\
\hline & $>40$ & 35 & 55 & 35 \\
\hline \multirow[t]{2}{*}{ Gender of respondents } & Female & 50 & 60 & 55 \\
\hline & Male & 50 & 40 & 45 \\
\hline General Awareness of Cactus & Not aware & 75 & 55 & 60 \\
\hline \multirow[t]{4}{*}{ Reason for introduction } & Ornamental & 10 & 50 & 40 \\
\hline & Crop & 5 & 0 & 0 \\
\hline & Live fence & 0 & 40 & 45 \\
\hline & Not sure & 85 & 10 & 15 \\
\hline \multirow[t]{3}{*}{ Those interested or against cacti } & Interested & 65 & 45 & 35 \\
\hline & Against & 5 & 5 & 10 \\
\hline & others & 0 & 0 & 0 \\
\hline \multirow[t]{4}{*}{ Reasons for interest or against Cacti } & Live Fence & 14 & 85 & 55 \\
\hline & Medicinal & 14 & 65 & 55 \\
\hline & Needles use & 0 & 0 & 10 \\
\hline & Nuisance & 0 & 0 & 10 \\
\hline \multirow[t]{6}{*}{ Current uses Cactus uses } & Food & 0 & 20 & 50 \\
\hline & Fodder & 0 & 60 & 70 \\
\hline & Income sources & 0 & 0 & 0 \\
\hline & Live Fence & 0 & 100 & 85 \\
\hline & Others (dye, needles) & 0 & 5 & 5 \\
\hline & No aware & 71 & 0 & 0 \\
\hline
\end{tabular}

Our results show wide utilization of $O$. ficus-indica as food (fruits) by both children and adults and fodder for livestock during dry period. The species were also found to play a significant role as sources of medicines, ornamental and needles in Maralal and Baragoi. Though cactus species may be associated with dense invasion of ASALs that result to negative effects on biodiversity, rangeland production and livestock [35], majority of local community in this region are still interested in having the cactus species for live fences $(51 \%)$, medicinal purposes $(44 \%)$ and provision of needles (3\%, Table 3). In Maralal and Baragoi, over $50 \%$ of respondents utilize Cactus fruits and fodder during extremely dry season while over $80 \%$ are still interested with the species $(O$. exaltata) for fencing (Table 3$)$. Their ability to thrive dry conditions, ability to form dense thickets that keep away small mammals (and cattle) from home compounds and production of fruits and fodder during extremely dry period were cited as the major reasons for their interest. Only $6 \%$ of person interviewed were against the species. They termed the species as nuisance due it rapid invasion, overgrowth and presence of thorns that made it hard to manage. In Loiyangalani cactus species were not available except for the recent introduction at the Catholic Church and youth camp explaining presence of greater proportion of the population $(70 \%)$ not aware of their common uses (Table 3 ).

Defensive and demarcative hedges were the major use cactus observed in this region. Although both O. ficus-indica and Opuntia exaltata are used as hedges, Opuntia exaltata 
was the most preferred species due to its ability to form very sharp spines and slender stems which entangle to form a very thick fence. Under controlled pruning Opuntia exaltata formed a very thick fence, but if left uncontrolled the species can become notorious and even hard to control. We did not record any uses of $C$. peruvians species in this area, probably because the species is not common, and majority of the local communities were not aware of it. Elsewhere, C. peruvians is an important desert crop grown mainly for fruits and ornamental $[32,33]$. It produces attractive, thornless, edible fruits, which are known as pitaya in Latin America [41].

\subsubsection{Potential Cultivation and Constraints Against Cactus Cultivation}

Opuntia ficus-indica is among the long-domesticated cactus crop and an important crop in agricultural economies which is being recognized as ideal crops for arid regimes throughout ASALs [6]. In this region O. ficus-indica is a valuable resource providing food (fruits), fodder and source of medicine during extremely dry periods when other plants couldn't thrive. However cultivation of $O$. ficus-indica crop for provision of food (fruits, vegetable) and fodder received mixed reactions (Table 4). In, Baragoi and Maralal only a small proportion of the people (20\%) interviewed supported their cultivation. However, in Loiyangalani, greater proportion of the people questioned $(75 \%)$ were excited about having an alternative source of fodder and food since only few plants thrive in this area. Majority in this region felt introduction of $O$. ficus-indica as a dryland plant can play a significant role in providing fodder for their animal and fruits.

Table 4. Potential Utilization and possible constraints against cultivation cactus (O. ficus-indica) for food (fruit), fodder, medicine, ornamentals and live fencing in Northern Kenya (Maralal, Baragoi and Loiyangalani region).

\begin{tabular}{|c|c|c|c|c|}
\hline & & Loiyangalani & Maralal & Baragoi \\
\hline & & $\%$ & $\%$ & $\%$ \\
\hline \multirow[t]{3}{*}{ Awareness of Cactus cultivation for food/fodder } & Yes & 25 & 20 & 5 \\
\hline & No & 10 & 80 & 95 \\
\hline & Not Sure & 60 & 0 & 0 \\
\hline \multirow{5}{*}{ Proportion for cultivation of Cactus } & Cultivate & 75 & 20 & 20 \\
\hline & Remove & 10 & 10 & 40 \\
\hline & Grow wild & 0 & 60 & 30 \\
\hline & Management needed & 15 & 10 & 5 \\
\hline & Not sure & 0 & 0 & 0 \\
\hline \multirow[t]{7}{*}{ Uses that may prompt need cultivation } & Fruits/food & 5 & 40 & 35 \\
\hline & Fodder & 5 & 45 & 45 \\
\hline & Medicine & 0 & 60 & 65 \\
\hline & Ornamental & 0 & 5 & 20 \\
\hline & Not Sure & 60 & 35 & 30 \\
\hline & Un-available & 30 & 0 & 0 \\
\hline & Others & 0 & 0 & 0 \\
\hline \multirow[t]{7}{*}{ Possible Constraints against cultivation } & Overgrowth & 5 & 55 & 55 \\
\hline & Thorns & 25 & 100 & 100 \\
\hline & Nuisance & 0 & 0 & 5 \\
\hline & Poisonous & 0 & 10 & 0 \\
\hline & Others & 5 & 0 & 0 \\
\hline & none & 5 & 0 & 0 \\
\hline & don’t know & 60 & 0 & 0 \\
\hline \multirow[t]{3}{*}{ Known effects on Plants or animals } & Yes & 0 & 0 & 0 \\
\hline & No & 80 & 85 & 100 \\
\hline & Not sure & 20 & 15 & 0 \\
\hline
\end{tabular}

Cultivation of Opuntia species has been successful in many developed countries due to their efficiency in converting water to dry matter, ability to withstand drought, prevent soil erosion and combat desertification [6]. In Northern Kenya, we predict an increase in exploitation of this crop in future due to expected prolonged drought periods with the changing climate. Our result has shown wide utilization of $O$. ficus-indica fruits as source of food and fodder during prolonged dry periods in this area. Additionally, our results have shown wide utilization of $O$. ficus-indica for medicinal purposes by local community mainly from the wild. This is an underutilization given that medicinal value of $O$. ficus-indica is well documented and medicines from this crop are being marketed in major pharmaceuticals of the world. For example, it has been reported that $O$. ficus-indica alleviates the symptoms of benign prostatic hyperplasia [36], lowers levels of cholesterol [37] and diabetics need for insulin [38,39], reduces hangover systems [40] and in-vivo oxidation injury in people suffering from hypercholesterolemia, and has significant cardiovascular benefit [41]. This indicates hidden potential of O. ficus-indica which needs to be explored to benefit local communities in Kenya especially regions where it has been naturalized or has dense infestations.

Cultivation of $O$. ficus-indica may have great potential in ASALs [6], but its implementation may pose great challenge especially managing and controlling its spread to nontargeted areas like national parks, grazing areas and riparian zones among others. Majority of respondents in this region cited thorns and overgrowth as the major constraints against 
cactus utilization and management (Table 4). A few felt some cactus were poisonous, hence their utilization is always taken in caution. Despite these constraints, the majority of people in Maralal $(60 \%)$ felt that, cactus species should be left to grow in the wild since they are a source of food and fodder to both man and animals during the dry season (Table 4). Furthermore majority of the local community in this area support its growth in the wild, as an alternative source of food and fodder especially in extremely drought period. This clearly show that with effective management options, cactus species can be manipulated as alternative sources of food, fodder and medicine in this region.

In Baragoi, only $30 \%$ of the people interviewed recommended its growth in wild, while greater proportion ( $40 \%)$ of the population recommended complete removal of cactus due constraints mentioned above (overgrowth and thorns). Majority of local community felt O. ficus-indica if left unmanaged colonizes fast forming dense thickets that are difficult to penetrate. Easiness for the species to proliferate has made it hard to control, while big thorns have made it hard to extract and manage. This has been the case in many other countries, where Opuntia species have often been reported as problematic weeds negatively affecting biodiversity and reducing production of grazing land [19, 42, 43]. Opuntia species are shown to outdo native botanical diversity and cause physical injury to native fauna [44]. Although biological control of these species has been successful in several countries, it is still a big problem in others. In northern Kenya, although we have shown overgrowth and thorns as major problems with the cactus species, the species are not yet a problematic weed like in many other countries. But owing to the fact that East Africa drylands have witnessed the introduction of various alien species in 1970s and 1980s (e.g. Prosopis species) which have become difficult and costly to control and eradicate, there is need for detailed studies on management options.

\section{Conclusions}

Our results clearly demonstrate that, cactus especially $O$. ficus-indica are valuable resource used as fruits and vegetables-cladodes, fencing, cattle fodder, cosmetics, natural medicines, and dye production. O. ficus-indica therefore can be developed to improve rural livelihood in this region. Exploring the utilization and cultivation of $O$. ficusindica spineless cultivar can add value to the cactus products in this region. O. ficus-indica spineless cultivar has been shown to be favoured in production in their native range, and don't appear to survive in the wild [44]. Cactus species have ability to spread causing damage to the environment, biodiversity, economy and health. Invasive species may cause harm to wildlife. They can breed and spread aggressively, taking over an area thus out-competing native plant species that are food for wildlife. Before any introduction, a wide knowledge on its reproduction, dispersal, habitat and its impacts to flora and fauna diversity as well as human will be necessary. Precaution is needed to avoid the disastrous consequences of poorly introduction of invasive exotic species. Any species proposed for introduction should be subject to rigorous risk assessment and ecological characterization prior to introduction.

\section{Acknowledgements}

This study was funded by Kenya Museums Society (KMS). We are grateful to Ali and Makabo from Loiyangalani Desert Museum for providing field guidance throughout the study.

\section{References}

[1] White, F. (1983). The Vegetation of Africa. Natural Resources Research, Vol. 20. UNSECO, Paris. pp. 1-356.

[2] Weiss, E. (1989). Guide to plants tolerant of Arid and semiarid conditions. Nomenclature and potential uses. Nairobi. Kenya.

[3] Nyffeler, R. (2002). Phylogenetic relationships in the cactus Family (cactaceae) based on evidence from trnk/matk and trnl-trnf sequences. American journal of botany 89 (2): 312 326.

[4] Novoa, A., Le Roux, J. J., Robertson M. P., Wilson J. R., \& Richardson, D. M. (2015). Introduced and invasive cactus species: a global review. AoB PLANTS. 7: plu078; doi: 10.1093/aobpla/plu078.

[5] Mizrahi, M. (1999). Beating the Odds: New Exotic DesertGrown Fruits. Examines a koubo orchard in Israel's inhospitable. Western Negev Desert.

[6] FAO. (2001). Cactus (Opuntia spp.) as forage. FAO Plant production and Protection Paper 169. FAO International Technical Cooperation Network on Cactus Pear. Food and Agriculture organization of the United Nations. Rome. www.fao.org.

[7] Barthlott, W., \& Hunt, D. R. (1993). Cactaceae. In K. Kubitzki, J. G. Rohwer, and V. Bittrich (eds.). The families and genera of vascular plants, vol. 2, 161-197. Springer Verlag, Berlin, Germany.

[8] Basile, F. (2001). Economic aspects of cactus pear production and market. Journal of the Professional Association for Cactus Development 5: 31-46.

[9] Ingelese, P., Basile, F., \& Schirra, M. (2002). Cactus pear fruit production. In P. S. Nobel [ed.], Cacti: biology and uses, 163183. University of California, Berkeley, California, USA.

[10] Barbera, G. Carimi, F., \& Ingelese, P. (1992). Past and present role of the Indian-fig prickly-pear (Opuntia ficus-indica (L.) Miller, Cactaceae) in the agriculture of Sicily. Economic Botany 46: 10-20.

[11] Sa'enz-Hernandez, C., Corrales-Garcia, J., \& Aquino-Pe'rez, Z. (2002). Nopalitos, mucilage, fiber, and cochineal. In P. S. Nobel [ed.], Cacti: biology and uses, 211-234. University of California, Berkeley, California, USA.

[12] Ca' rdenas, A., Arguelles, W., \& Goycoolea, F. (1998). On the possible role of Opuntia ficus-indica mucilage in lime mortar performance in the protection of historical buildings. Journal of the Professional Association for Cactus Development 3. 
[13] Emmart, E. W. (1940). The Badianus manuscript. The John Hopkins Press, Baltimore, Maryland, USA.

[14] Donkin, R. (1977). Spanish red: an ethnogeographical study of cochineal and the Opuntia cactus. Transactions of the American Philosophical Society 67: 1-77.

[15] Nobel, P. S. (1994). Remarkable agaves and cacti. Oxford University Press, New York, New York, USA.

[16] Anderson, E. (2001). The cactus family. Timber Press, Portland, Oregon, USA.

[17] Novoa, A., Kaplan, H., Wilson, J. R., \& Richardson, D. M. (2016). Resolving a prickly situation: involving stakeholders in invasive cactus management in South Africa. Environ Manag 57: 998-1008.

[18] CABI (2016) Opuntia stricta. In: Invasive species compendium. $\mathrm{CAB}$ International, Wallingford. www.cabi.org/isc. Accessed 20 Sept 2016.

[19] Shackleton, R. T., Witt, B. R., Piroris, F. M., \& Wilgen (2017). Distribution and socio-ecological impacts of the invasive alien cactus Opuntia stricta in eastern Africa Biological Invasions, 19 (8) pp 2427-2441.

[20] Foxcroft, L. C., Rouget, M., Richardson, D. M., \& MacFayden, S. (2004). Reconstructing 50 years of Opuntia stricta invasion in the Kruger National Park, South Africa: environmental determinants and propagule pressure. Divers Distrib 10: 427-437.

[21] Greathead, D. J. (1971). A review of biological control in the Ethiopian region. Technical Communications No. 5, Commonwealth Institute of Biological Control, Commonwealth Agricultural Bureaux, Slough, pp 1-162.

[22] Shackleton S, Kirby D, Gambiz J (2011) Invasive plantsfriends or foes? Contribution of prickly pear (Opuntia ficusindica) to livelihoods in the Makana Municipality, Eastern Cape, South Africa. Dev South Afr 28: 177-193.

[23] Dodd, A. P. (1936). The control and eradication of prickly pear in Australia. Bulletin of Entomological Research 27: 503-517.

[24] Grant, V., \& Grant, K. A. (1971). Dynamics of clonal microspecies in cholla cactus. Evolution 25: 144-155.

[25] Cronk, C. B., \& Fuller, J. L. (1995). Cronk, Plant Invaders. Chapman \& Hall, London.

[26] Magurran, A. E. (1988). Ecological diversity and its measurement. Princeton University Press, Princeton, New Jersey, 192, 35, 1988.

[27] Hammer, R., Harper, D. A. \& Ryan, P. D., (2001). PAST: Paleontological Statistics Software Package for Education and Data Analysis-Palaeontol. Electron. 4: 9pp.

[28] Pholhil, R. M., \& Redhead, M. E. (1968). Flora of Tropical East Africa, Royal Botanical Gardens, Kew.

[29] Casa, A., Caballero, J., Mapes, C., \& Za'rate, S. (1997). Manejo de la vegetacio'n, domesticacio'n de plantas y origin de la agricultura en Mesoame 'rica. Boletý'n de la Sociedad Bota'nica de Me'xico 61: 31-47.
[30] Casa, A., \& Barbera, G. (2002). Mesoamerican domestication and diffusion. In P. S. Nobel [ed.], Cacti: biology and uses, 143-162. University of California, Berkeley, California, USA.

[31] Irish, P. (2001). The ornamental prickly pears industry in South Western United state, Florida. Entomologist 84 (4).

[32] Nerd, A., and Mizrahi, Y. (1997). Reproductive biology of cactus fruit crops. Hort. Rev. 18: 321-346.

[33] Nerd, A., Raveh, \& Mizrahi, Y. (1993). Adaptation of five columnar cactus species to various conditions in the Negev Desert of Israel. Economic Botany. 43: 31-41.

[34] Weiss, J., Nerd, A. \& Mizrahi, Y. (1993). Development of the apple cactus (Cereus peruvianus) as a new crop to the Negev Desert of Israel. P. 486-491. In: J. Janick and J. E. Simon (eds.), New crops. Wiley, New York.

[35] Vilá, M., Burriel, J. A., Pino, J., Chamizow, J., Llachw, E., Porterias, M., \& Vives, M. (2003). Association between Opuntia species invasion and changes in land cover in the Mediterranean region. Global Change Biology, 9, 1234-1239.

[36] Hodkinson, D. J., \& Thompson, K. (1994). Plant dispersal: the role of man. Journal of Applied Ecology, 34, 1484-1496.

[37] Wolfram, R., Budinsky, A., Efthimiou, Y., Stomatopoulos, J., Oguogho, A., \& Sinzinger, H. (2003). Daily prickly pear consumption improves platelet function. Prostaglandins Leukotrienes and Essential Fatty Acids, 69 (1) 61-66.

[38] Trejo-Gonzalez, A, Gabriel-Ortiz, G., Puebla-Perez, A. M., Huizar-Contreas, M. D., Munguia-Mazariegos, M. R., MejiaArregin, S., \& Calva, E. (1996). A purified extract from prickly pear cactus (Opuntia fuliginosa) controls experimentally induced diabetes in rats. Journal of Ethnopharmacology 55: 27-33.

[39] Jose, L. L. (2007). Use of Opuntia Cactus as a Hypoglycemic Agent in Managing Type 2 Diabetes Mellitus among Mexican American Patients, Nutrition Bytes. 12 (1): 2 http://repositories.cdlib.org/uclabiolchem/nutritionbytes/vol12 /iss1/art2.

[40] Wiese, J., Mapherson, S., Michelle, C., \& Odden, B. (2004). Effect of Opuntia ficus-indica on symptoms of alcohol hang over. Arch Intern. Med. 164: 1334-1340.

[41] Budinsky, A., Wolfram, R., Oguogho, A., Efthimiou, Y., Stamatopoulos, Y. \& Sinzinger, H. (2001). Regular ingestion of opuntia robusta lowers oxidation injury. Prostaglandins Leukot Essent Fatty Acids, 65 (1): 45-50.

[42] Dodd, A. P. (1940). The biological campaign against prickly pear. Commonwealth Prickly Pear Board, Brisbane.

[43] Griffith, M. P. (2004). The origins of an important cactus crop, Opuntia ficus-indica (Cactaceae): new molecular evidence. American journal of Botany. 91 (11): 1915-1921.

[44] Greenfield, B. \& Nicholson, H. (2007). SA Arid Lands Opuntia species management plan, DRAFT. South Australian Arid Lands Natural Resource Management Board. 